\title{
Testing the ability of an empirical hydrological model to verify a knowledge-based groundwater potential zone mapping methodology
}

\author{
O. O. Aladejana' ${ }^{1}$ A. Y. B. Anifowose ${ }^{1}$ B. J. Fagbohun ${ }^{1}$
}

Received: 19 August 2016/Accepted: 27 September 2016/Published online: 5 October 2016

(C) Springer International Publishing Switzerland 2016

\begin{abstract}
Groundwater potential characterization is a major component of the developmental strategies required for sustainable management of the water resources of a country. This study explores the potential of Natural Resources Conservation Service (NRCS-CN) estimated runoff/infiltration to verify a knowledge-based groundwater potential zone mapping methodology using remote sensing and GIS. Eight criteria/factors regarded as positive indicators to the existence of groundwater in the study area were mapped and weighted based on the knowledge of the local geology using analytical hierarchy process (AHP). The results from AHP were integrated using Weighted Index Overlay Analysis in a GIS environment to delineate the groundwater potential map of the area. Five classes consisting of very good, good, moderate, fair and poor groundwater potentials, each occupying $4.6,53.3,82.22$, 37.47 , and $0.43 \mathrm{~km}^{2}$, respectively, were delineated. They were found to be in agreement with the borehole information of the area. Curve number $(\mathrm{CN})$ for the various land cover types was generated using the NRCS-CN approach. $\mathrm{CN}$ was used to compute a qualitative, terrain-based, runoff/infiltration response for rainfall events in the study area, from which a terrain-based runoff map of the area was computed. A comparison between the groundwater potential map and terrain-based runoff map was done using linear regression analysis. The coefficient of determination $\left(R^{2}\right)$ obtained was 0.80 . The result indicates a high application efficiency of NRCS-CN method in verifying the
\end{abstract}

O. O. Aladejana

ooaladejana@futa.edu.ng

1 Department of Remote Sensing and Geoscience Information System, The Federal University of Technology, Akure, Ondo State, Nigeria accuracy of a GIS-based qualitative groundwater potential mapping.

Keywords Hydrological modeling · Analytical hierarchy process - Weighted Index Overlay Analysis - NRCS-CN · GIS $\cdot$ Remote sensing

\section{Introduction}

Water is an important resource for all forms of life on planet earth. Its significance to humans for agricultural, domestic, transportation, industrial and recreational purposes cannot be over emphasized. This makes it critical to the sustainable development of any region of the world. Being a finite, scarce and vulnerable resource, there has been growing pressures on its abstraction in different parts of the world to satisfy human uses (Rockstrom et al., 2007). Around the world the occurrence of freshwater varies spatially with less than 10 countries having about $60 \%$ of the world's freshwater (Donkor 2003). Furthermore changing climatic pattern has birthed increasing frequencies of extreme events such as heavy rainfall and drought, making surface water inaccessible. There is an increasing demand for water to meet domestic uses, as well as industrial and agricultural requirements (de Vries and Simmers 2002). To effectively exploit the water resources of an area, it is imperative to map its groundwater potential zones (Maheswaran et al. 2016). This is because productive aquifer zones are localized, and vary with distance (Satpathy and Kanungo, 1976). It has been recognized that an effective and practical way of exploring groundwater resources is by establishing a groundwater potential prediction model (Adiat et al. 2012; Mogaji et al. 2014). As groundwater varies spatio-temporally within a particular 
area, the major determinants of this variability are factors such as geology, geomorphology, land cover, precipitation, fractures (lineaments), slope, and soil (Singh et al., 2011). Traditional approaches of groundwater exploration through drilling, geological and geophysical methods are cost intensive and time consuming (Sander et al. 1996; Singh and Prakash, 2002). The application of remote sensing and Geographic Information System (GIS) in this endeavour has made exploration much easier (Singh and Prakash 2002). This is because information on surface features related to groundwater occurrences can be mapped, integrated with other tabular data, and spatially analysed in a GIS environment (Jha et al. 2007). Remote sensing and GIS-based groundwater potential zone mapping, a qualitative technique, involves the application of surface evidences, e.g. geology, soils, land use/land cover (LULC) derived from satellite imageries to infer zones of groundwater accumulation (Jha and Peiffer 2006). Several researches has been conducted on the application of remote sensing using multi-criteria decision making techniques for groundwater potential mapping in both basement complex and sedimentary environments. While some workers simply use a combination of remote sensing and GIS techniques alone (Kamaraju et al. 1996; Saraf and Choudhury 1998; Kumar 1999; Krishnamurthy et al. 2000; Sahid and Nath 2002) others used index-based models (Ganapuram et al. 2009; Suja and Krishnan 2009) such as AHP (Chowdhury et al. 2010; Machiwal et al. 2010; Dar et al. 2010; Khodaei and Nassery 2011; Abdalla 2012; Gumma and Pavelic 2013; Sharma et al. 2014, Mogaji et al. $2014,2016)$ to determine groundwater potential zones. In recent years, soft computing techniques such as fuzzy logic (Shahid et al. 2002; Ghayoumian et al. 2007), numerical modelling and decision tree (DT) (Chenini and Mammou 2010) have also been applied to various groundwater conditioning factors for groundwater potential mapping. The methodologies described above have found strong acceptance in the scientific community. Furthermore, in a tropical rainforest, infiltration of rainfall and surface runoff in ephemeral streams are the most significant sources of groundwater recharge (Dinicola 1997). Infiltration here refers to the downward flow of moisture under the influence of gravity through an aeration zone. Through this zone, infiltration recharge of groundwater occurs under conditions of incomplete saturation of soil moisture zones. When the zone of aeration in soils are dried up, the first part of infiltrating rainfall is used in the saturation of dried zone to the maximum molecular level firmly retained by soils and rock particles, after which gravitational groundwater recharge occurs (Kovalevsky 2009). Runoff is the net liquid water supplied to channels after evaporation, interception, surface retention, infiltration and percolation to underlying aquifers (Sharma et al. 2001); and infiltration is usually the main factor affecting the amount of water available for runoff (Bras 1990). Therefore, "the lower the infiltration, the higher the runoff potential will be". The amount of rainfall that will eventually infiltrate into an aquifer to join groundwater, or become surface runoff can be determined using the Soil Conservation Service (SCS) method [now Natural Resources Conservation Service (NRCS) method] (Zhan and Huang 2004, Weng 2001). From being an empirical model initially developed to estimate runoff from rainfall events on agricultural fields, it has evolved into applications for computing peak runoff rates and volumes for urban hydrology, especially in ungauged basins such as the study area. It joins the NRCS runoff equation with unit hydrograph theory for the computation of runoff rates. The curve number $(\mathrm{CN})$ is essentially a coefficient that reduces the total precipitation to runoff potential, after "losses" through evaporation, absorption, transpiration, and surface storage. The integration of SCS-CN with GIS has proven to be very efficient as it helps to facilitate the analysis of large volumes of watershed data whilst augumenting the accuracy of computed data (Zhan and Huang 2004). Over the years, many researchers have used the SCS-CN method and similar approaches to estimate runoff (Gitika and Rajan 2014; Lim et al. 2006; Mishra and Singh 1999; Debo and Reese 2002). A whole lot of watershed models such as AGNPS (Young et al. 1987), EPIC (Williams 1995), SWAT (Arnold et al. 1996); and WMS (http://www.ems-i.com/WMS/WMS_ Overview/wms_overview.html) have their methodologies for computing runoff built on the $\mathrm{CN}$ approach. Therefore, there is a connection between infiltration, runoff, and groundwater recharge into aquifers as relating to surface conditions of land cover, soil, and terrain properties, of an area. In view of these, this study aims to delineate the groundwater potential zones in the study area and to verify the results using borehole data and runoff.

\section{The study area}

Akure city covers an area of about $180 \mathrm{~km}^{2}$. It is the capital of Ondo State, south western Nigeria. It lies between Latitudes $7^{\circ} 13^{\prime} 00^{\prime \prime} \mathrm{N}-7^{\circ} 17^{\prime} 00^{\prime \prime} \mathrm{N}$ and Longitudes $5^{\circ} 09^{\prime} 00^{\prime \prime} \mathrm{E}-5^{\circ} 14^{\prime} 00^{\prime \prime} \mathrm{E}$ (Fig. 1).

The topography of Akure is undulating with slopes ranging between $0^{\circ}$ and $30^{\circ}$. More than $70 \%$ of rainfall occurs in the rainy season (May to September). The study area is mainly drained by River Owena on the west. The climate is sub-tropical, and monthly temperature varies between $23-29{ }^{\circ} \mathrm{C}$. Geologically, it belongs to the migmatite-gneiss complex which is a part of the Precambrian basement complex of Nigeria (Jones and Hockey 1964; Rahaman 1988; Dada 2006). The age of the migmatite gneiss complex ranges from Pan African to Eburnean, and 


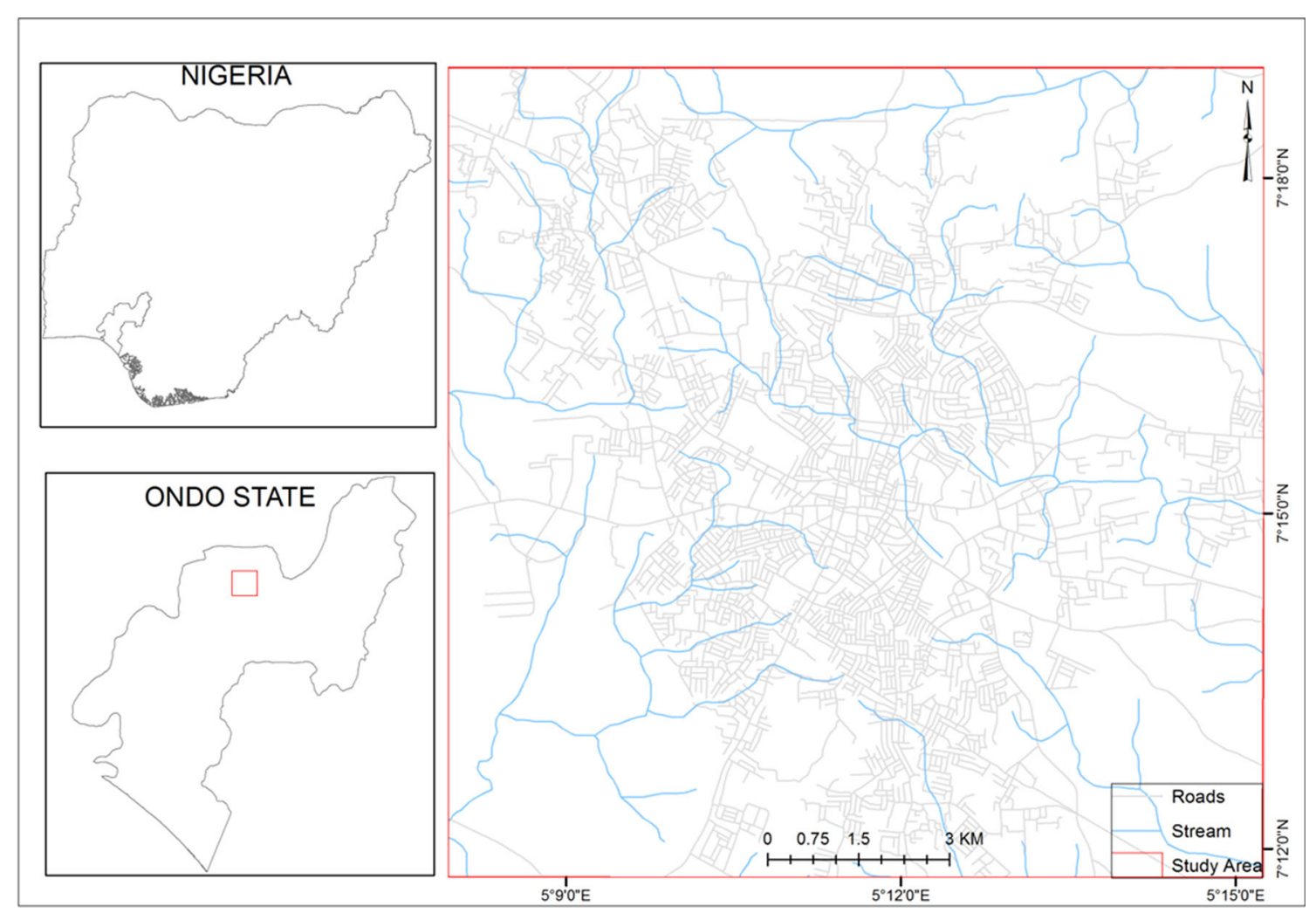

Fig. 1 Location map of Akure area

they exhibit a complex deformation style which underlies its polycyclic nature (Odeyemi et al. 1999). Distinct petrological units recognised in Akure include charnockites, migmatite gneisses, granite gneisses, biotite granites, porphyritic granites and quartzites (Anifowos 2000). They exhibit varieties of structural features such as foliations, folds and fractures. The general trend of the rocks is in the NNE-SSW direction, while several short fractures trend $\mathrm{N}-\mathrm{S}$ (Atejioye and Anifowose 2005). They possess low porosity and with little or no permeability, a characteristic of crystalline basement complex rocks. However, local and regional evidence of localized and discontinuous complex faulting and folding as a result of tectonic activities (Olorunfemi et al. 1999; Bala and Ike 2001) have resulted in both secondary and dual porosities in these rocks. The groundwater potential in the area depends largely on the properties of the overburden and underlying aquifers.

\section{Methodology}

In order to produce a reliable and precise groundwater model and infiltration vis-à-vis runoff of the study area, a spatial database consisting of several remotely sensed, ground and ancillary data was constructed (Table 1). The methodology employed is summarized in Fig. 2. Hardcopy maps were scanned and georeferenced to UTM, WGS 1984
Northern Hemisphere Zone 31. Remote sensing and GIS analysis carried out involved pre-processing, image transformation, image enhancement, filtering, and classification. Land cover, lineament density, lithology, soil, borehole discharge, rainfall distribution, drainage density, slope and geomorphology were extracted. These parameters control the spatial, temporal and volumetric occurrence of groundwater, and runoff in the study area.

\section{Multi-criteria approach to groundwater modelling using Analytical Hierarchy Model (AHP)}

The ability of multi-criteria techniques to effectively combine several factors for proper decision making has increased its use in groundwater hydrology (Adiat et al. 2012; Mogaji et al. 2014; Zhou and Chen 2014). Of all MCDM techniques, AHP is the most commonly used MCDM technique in groundwater studies due to its robust capability in the conjunctive and integrated analysis of multidisciplinary datasets (Madan et al. 2010). In AHP (Saaty 1980; Saaty 1990), a complex decision problem is broken down into smaller units, resolved and aggregated back to a larger unit. AHP relies on the judgement of experts to derive priority scales. In this study, opinion on groundwater accumulation in the study area from seven experts was gathered through questionnaires. After 
Table 1 Information and sources of data used in this study

\begin{tabular}{llllll}
\hline Types of data & Details of data & Format & Extracted layer & Generated layers & Data type \\
\hline RS imagery & Landsat 82015 & TIFF & Land cover & Land cover & Raster \\
& & & Lineament & Density & Raster \\
Geological map $^{\mathrm{b}}$ & 1: 100000 & Hardcopy & Lithology & Lithology & Vector \\
Soil map $^{\mathrm{c}}$ & 1: 500000 & Hardcopy & Soil & Soil types & Vector \\
Borehole records $^{\mathrm{d}}$ & Borehole data & Excel & Discharge & Discharge & Raster \\
Rainfall data $^{\mathrm{e}}$ & NIMET & Excel & Distribution & Rainfall distribution & Raster \\
Topographic map $^{\mathrm{f}}$ & OSGOF & Hardcopy & Drainage pattern & Drainage density & Raster \\
ASTER DEM $^{\mathrm{g}}$ & DEM & TIFF & Slope & Slope & Raster \\
& & & Geomorphology & Geomorphology & Raster
\end{tabular}

${ }^{\mathrm{a}}$ Remotely sensing imagery downloaded free from the Global Land Cover Facility homepage (http://glcf. umiacs.umd.edu/index.shtml)

b Geological map obtained from the Nigerian Geological Survey Agency (NGSA)

c Soil derived from crystalline rocks of western Nigeria (Smyth and Montgomery, 1962)

d Borehole records (which include lithologs and pumping test results) were obtained from Ondo State Water and Sanitation project (WATSAN)

e Rainfall data obtained from Nigerian Meteorological Agency

f Topographic map obtained from Office of the Surveyor General of the Federation

g ASTER DEM downloaded from NASA's Land Processes Distributed Active Archive Center (LP DAAC)

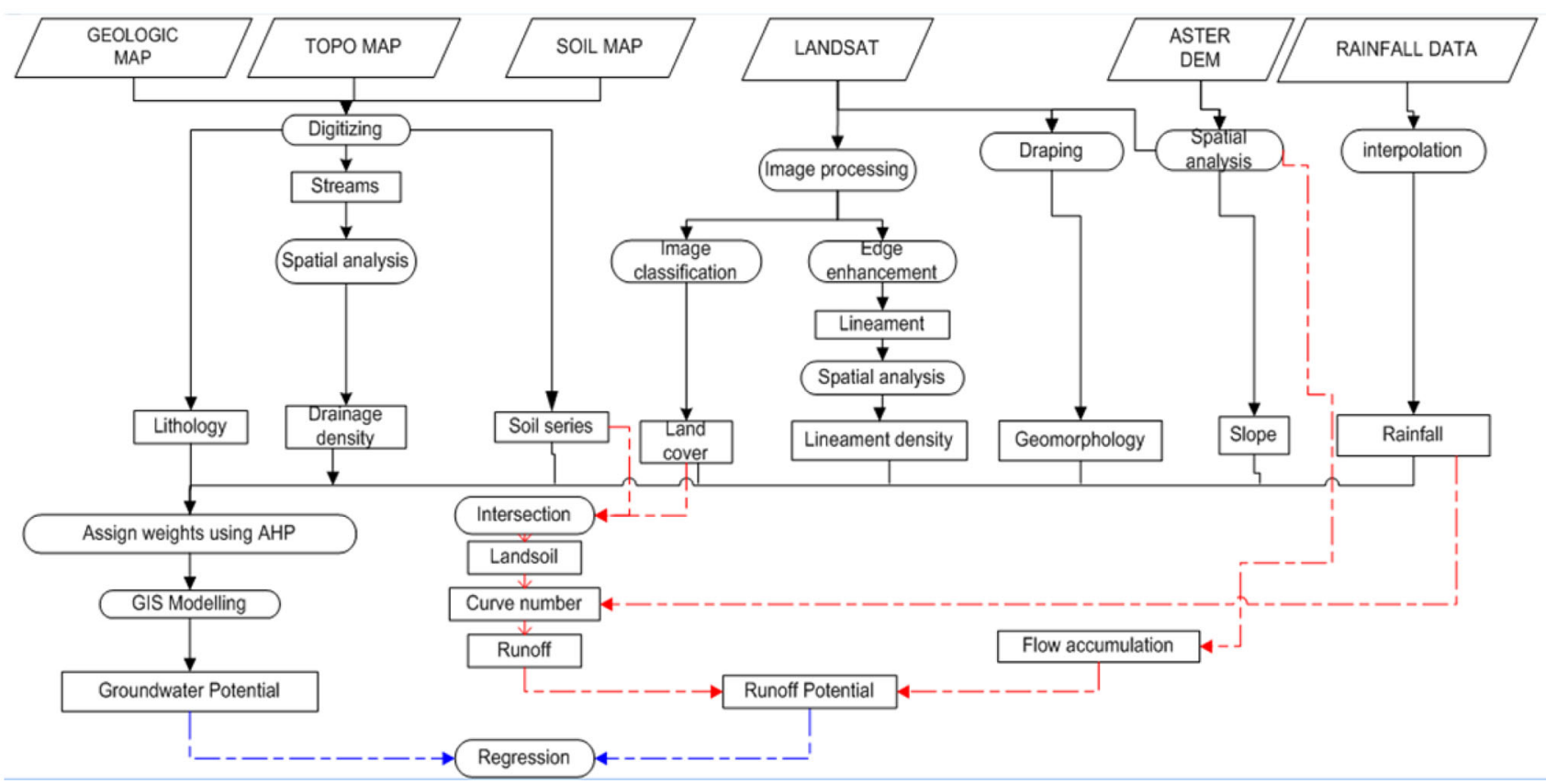

Fig. 2 Schematic representation of computational methodology

analysis, comparison between and within thematic layers based on their contribution to groundwater accumulation was done on a scale of 1-9 (Table 2).

\section{Pair-wise comparison of thematic layers}

Using the $8 \times 8$ matrix for pair wise comparison between thematic layers, three crucial steps were further performed to calculate the normalized principal eigenvector.
In Step 1, the values of $j$ (column) were added up, while in Step 2, each element of the column was divided by the corresponding sum of the column to derive the relative weight matrix. In Step 3, the normalized principal eigenvector was obtained by averaging across the rows. This provided the factor weights which were further normalized by multiplication by 100 (Table 3 ). This was repeated to generate pair wise comparison within factors (Class Rank). 
Table 2 Measurement scale of AHP (Saaty 1980)

\begin{tabular}{ll}
\hline Intensity of importance & Definition \\
\hline 1 & Equal importance \\
2 & Equal to moderate importance \\
3 & Moderate importance \\
4 & Moderate to strong importance \\
5 & Strong importance \\
6 & Strong to very strong importance \\
7 & Very strong importance \\
8 & Very to extremely strong importance \\
9 & Extreme importance \\
\hline
\end{tabular}

As a rule of thumb in checking the consistency of the comparison, the consistency ratio (CR) must always be $\leq 0.1$ for an acceptable comparison. If the ratio is $>0.1$, the matrix should be re-evaluated (Sani et al. 2010)

The consistency ratio is calculated as follows

$C R=C I / R I$

where $C I$ is consistency index and $R I$ is random consistency index.

$C I=\left(\lambda_{\max }-n\right) /(n-1)$

where $\lambda_{\max }$ is the principal eigenvalue and $n$ is the number of comparisons.

The random consistency indices used to calculate the consistency ratio is shown in Table 4.

The consistency check for the thematic layers used in the groundwater potential mapping are $\lambda_{\max }=8.91828$, $C I=0.131182, \mathrm{n}=8, C R=0.09303$ which is far less than the threshold level of $0.1, R I=1.41$ (from Table 4). This indicates a high level of consistency.

\section{Weighted Index Overlay Analysis}

The weighted index overlay analysis is a straightforward method for combined analysis of multiclass maps to achieve a particular objective. The major advantage of this technique is that knowledge and experience-based human judgment can be incorporated into the analysis. The weights assigned here signify the relative importance of a factor vis-à-vis the overall objective. Most importantly, it considers the relative importance of the factors and the attributes of each factor. As there is no standardized scale for this method, the criteria for assigning weights should be well defined, and appropriate weights assigned to each factor (Saraf and Choudhury 1998). The eight (8) prepared thematic maps were overlaid to delineate the groundwater potential using weighted index overlay (Eq. 3) as summarized in Table 9.

$\frac{\sum w_{i} s_{i j}}{\sum w_{i}}$

where $w_{i}$ is the weight of ith factor map, $s_{i j}$ the spatial class weight of jth factor map, $s$ is the spatial unit value of the output map.

\section{Hydrological modelling for runoff using SCS-CN}

The curve number $(\mathrm{CN})$ is essentially a coefficient that reduces the total precipitation to runoff potential, after

Table 3 Pair-wise comparison between thematic layers

\begin{tabular}{|c|c|c|c|c|c|c|c|c|c|c|}
\hline & Geology & Geomorphology & $\begin{array}{l}\text { Lineament } \\
\text { density }\end{array}$ & Slope & Soil & $\begin{array}{l}\text { Drainage } \\
\text { density }\end{array}$ & $\begin{array}{l}\text { Land } \\
\text { cover }\end{array}$ & Rainfall & $\begin{array}{l}\text { Weights } \\
\text { (Eigen vector) }\end{array}$ & Weights $\times 100$ \\
\hline Geology & 1 & 2 & 2 & 4 & 5 & 6 & 7 & 8 & 0.295915 & 30 \\
\hline Geomorphology & & 1 & 2 & 3 & 4 & 5 & 6 & 7 & 0.221452 & 22 \\
\hline $\begin{array}{l}\text { Lineament } \\
\text { density }\end{array}$ & & & 1 & 3 & 4 & 5 & 6 & 7 & 0.18796 & 19 \\
\hline Slope & & & & 1 & 3 & 4 & 6 & 6 & 0.118705 & 12 \\
\hline Soil & & & & & 1 & 3 & 4 & 6 & 0.074702 & 7 \\
\hline $\begin{array}{r}\text { Drainage } \\
\text { density }\end{array}$ & & & & & & 1 & 4 & 5 & 0.051104 & 5 \\
\hline Land cover & & & & & & & 1 & 5 & 0.031936 & 3 \\
\hline Rainfall & & & & & & & & 1 & 0.018226 & 2 \\
\hline
\end{tabular}

Table 4 Random indices for matrices of various sizes

\begin{tabular}{lllllllllll}
\hline $\begin{array}{l}\text { Matrix } \\
\text { size }\end{array}$ & 1 & 2 & 3 & 4 & 5 & 6 & 7 & 8 & 9 & 10 \\
\hline RI & 0 & 0 & 0.58 & 0.9 & 1.12 & 1.24 & 1.32 & 1.41 & 1.45 & 1.49 \\
\hline
\end{tabular}


"losses" through evaporation, absorption, transpiration, and surface storage. It is based on the water balance equation as described in Eqs. 4 and 5 (Deshmukh et al. 2013; Soulis and Valiantzas 2012):

$P=I_{a}+F+Q$

$Q /\left(P-I \_a\right)=F / S$

The SCS-CN is expressed by the following equations

$Q=\frac{\left(P-I_{a}\right)^{2}}{P-I_{a}+S} \quad$ if $P>I_{a}$

$Q=0$ otherwise $I_{a}=\lambda S$

where $\mathrm{Q}$ is the direct runoff $(\mathrm{mm}), P$ is the total precipitation $(\mathrm{mm}), I_{a}$ is the initial abstraction $(\mathrm{mm}), S$ is the potential maximum retention $(\mathrm{mm}), \lambda$ is the initial abstraction coefficient (dimensionless).

The $\mathrm{S}$ parameter is expressed as

$S=\frac{25400}{C N}-254$

where $C N$ is the curve number, which depends on the soil type, land cover, hydrological conditions, and antecedent moisture condition (AMC).

The integration of SCS-CN with GIS has proven to be very efficient as it helps to facilitate the analysis of large volumes of watershed data whilst augumenting the accuracy of computed data (Zhan and Huang 2004). The land use/cover image was converted from raster to vector data models. The hydrological soil group (HSG) classification was used in the soil analysis for runoff (Table 4). The runoff potential of the Land-Soil complex of the study area i.e. the watershed potential also known as the runoff $\mathrm{CN}$ was determined by the intersection of the land cover and soil maps. The generated $\mathrm{CN}$ values range between $0-100$ (Table 5).

A CN value of 100 indicates that there is no infiltration, as all rainfall is transformed into direct runoff, while 0 indicates that there is no direct runoff as all rainfall infiltrates into the subsurface. The analysis was found to underestimate the predevelopment curve number, making it conservative, hence it was accepted. The antecedent

Table 5 Curve number estimation

\begin{tabular}{lllll}
\hline Land cover & \multicolumn{4}{l}{ Hydrologic soil group } \\
\cline { 2 - 5 } & A & B & C & D \\
\hline Bare surface & 39 & 61 & 74 & 80 \\
Settlement & 61 & 75 & 83 & 87 \\
Forest & 40 & 66 & 77 & 85 \\
Wetland & 30 & 55 & 70 & 77 \\
Rock & 98 & 98 & 98 & 98 \\
Arable land & 77 & 86 & 91 & 94 \\
\hline
\end{tabular}

moisture condition, an index of wetness in the study area was also considered. It was determined according to Guta and Panigraphy (2008), where AMC I is rainfall $<35 \mathrm{~mm}$; AMC II is rainfall $\geq 35 \mathrm{~mm}$ and $\leq 52.5 \mathrm{~mm}$; AMCIII is rainfall $>52.5 \mathrm{~mm}$. In view of this, AMC II was selected and adjustment of $\mathrm{CN}$ was done accordingly. The runoff that occurred in the study area was calculated based on the fact that for any rainfall event, the ratio of actual retention of soil after runoff begins to the potential maximum retention of soil is equal to the ratio of direct runoff to rainfall (Ponce and Hawkins 1996). This is exemplified by the equations below:

runoff $=\frac{(\text { rainfall }-0.2)^{2}}{\text { rainfall }+0.8 S} \quad$ if rainfall $>0.2 S$

runoff $=0$ if rainfall $<0.2 S$

where $\mathrm{S}=1000 / \mathrm{CN})-10$ in inches and $\mathrm{S}=(25,400 /$ $\mathrm{CN})-254$ in $\mathrm{mm}$, SI units.

\section{Result and discussion}

\section{Factors peculiar to groundwater accumulation in the study area}

Groundwater occurrence/accumulation in any particular region depends on many factors that act either locally or regionally (Nolan et al., 2007). In the study area, these factors include land cover, lineament density, lithology, soil, borehole discharge, rainfall distribution, drainage density, slope and geomorphology.

\section{Geomorphology}

For the evaluation of groundwater resources, a geomorphological terrain classification is useful, as it takes both morphological and lithological factors into consideration (Aladejana 2012). In hard rock terrains such as the study area, relief, slope, depth, type of weathered materials, and the overall characteristics of different landforms play an important function in groundwater accumulation (Karanth 1987). As landforms are the most common features encountered by any one engaged in geological field work, proper interpretation of them sheds light upon the geologic history, structure and lithology and hydrogeologic status of an area. Digital elevation models (DEM) allows the creation of detailed description of landforms that are useful for groundwater potential assessment (Semere 2003). It also plays an important role in the identification of favourable zones for groundwater accumulation. Flood plains, alluvial fans and valley associated with thick alluvium and weathered materials have high porosity and permeability, 


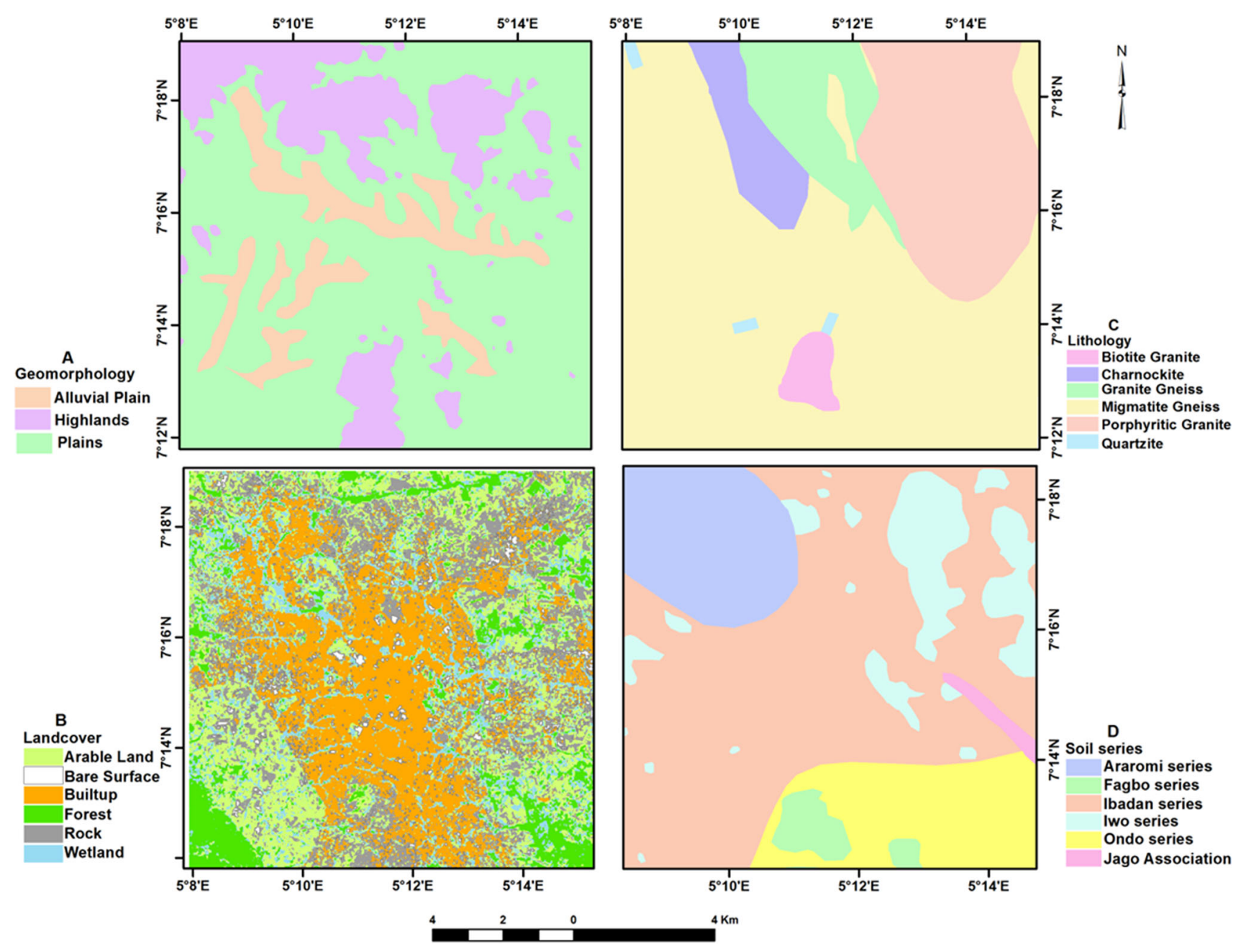

Fig. 3 a Geomorphology, b land cover, $\mathbf{c}$ lithology, $\mathbf{d}$ soil series

making them favourable areas for groundwater accumulation. Pediments generally are not favourable for groundwater accumulation zones. From the DEM of the study area, the slope amount coupled with the contour was used to generate the basic geomorphologic classes in the study area (Fig. 3a). After field survey, highlands, alluvial plains and plains were obtained as the major geomorphologic classes present in the study area. The highlands in the study area are formed by porphyritic granites in the north eastern part, and biotite granites in the southern part. Alluvial plains are occupied by very porous and permeable materials which are excellent hosts for groundwater accumulation.

\section{Land cover}

Land cover is also a major parameter that affects the accumulation of groundwater in an area. They affect groundwater accumulation by either increasing or reducing run-off. The intersection of rainfall by leaves further increases the possibility of infiltration through the soil. This is in direct contrast with bare surfaces, which permit runoff as a result of the high velocity of impact on the ground surface. In the study area, the land cover types were bare land, arable land, dense forest, built-up, and water body. The land cover of the study area was derived from Landsat 8 imagery acquired in 2015. Rectified images were subjected to supervised classification with five (5) classes using the maximum likelihood algorithm in ERDAS Imagine ${ }^{\circledR}$. The classes (Fig. 3b) obtained were verified using pattern recognition through ground truthing and fieldwork.

\section{Lithology}

Lithology is the physical characteristic of a rock that is visible at the surface; it is used as a basis for subdividing rock sequences for mapping and verification purposes (Sahl 1987). The lithologic map of the study area was obtained by scanning, georeferencing and sub-mapping of a larger 
geological map obtained from the Nigerian Geological Survey Agency (NGSA). Field study was conducted to verify the information obtained and several changes were made to produce the final geological map (Fig. 3c). The various lithologic units in the study area are quartzite, biotite granite, porphyritic granite, granite gneiss, migmatite gneiss and charnockite. Most of these rocks have been subjected to tectonic stress after emplacement. As a result of this, they have become fractured, serving as conduits for groundwater flow. Granites and quartzites fracture in similar ways because of their brittle nature. In contrast to these characteristics, the migmatite and gneisses are characterized by ductile deformation, making them poor hosts for groundwater. However, the zones dominated by these two rocks offer the best sites for borehole location and hand dug wells based on their high lineament density (Mogaji et al. 2016), while areas dominated by migmatites and gneisses only produce wells with low yield except when fitted with submersible pumps for maximum drawdown. It should be noted that charnockites have the poorest water bearing capacities because of their low level of secondary porosity. Also, they weather into clay which does not support groundwater accumulation.

\section{Soil}

Soils in an area affect the accumulation of groundwater by how much permeation takes place. According to Murthy (2000), groundwater recharge and runoff characterizing an area is largely dependent on the soil characteristics. A local soil classification scheme proposed by Smyth and Montgomery (1962) peculiar to south western Nigeria was employed in this study. It involved breaking down soil associations into smaller mappable units referred to as Soil Series. The study area consists of Iwo, Itagunmodi, Ondo and Jago associations. Further classifications were carried out after field survey to extract the distinct soil series from these associations. These gave rise to the Iwo, Ibadan, Araromi, Fagbo, and Ondo Series. However, the Jago Association could not be classified into series because it does not vary in origin. They are all of the same texture and composition (Fig. 3d). The soil series were classified based on their clay and sand contents (Table 6). The hydrologic soil groups for each soil type were also determined based on their textures obtained from laboratory analysis: HSG A for sand, loamy sand or sandy loam; HSG B for silt loam or loam; HSG C for sandy clay loam; and HSG D for clay loam, silty clay loam, silty clay or clay texture soils (USDA-SCS, 1986).

\section{Lineament density}

Lineaments are any observable geomorphic linear feature that can be attributed to geological structures, notably fractures, or lithologic contacts (O'Leary et al. 1976). Zones of lineament occurrence represent weak zones, typifying fissures/joint, fractures, and probably weathered formations (Chowdhury et al. 2009). The lineaments occurring in the study area was extracted from the Landsat and DEM datasets using Envi $4.3^{\mathrm{TM}}$ and ArcGIS ${ }^{\mathrm{TM}}$. Image enhancement, Normalized Difference Vegetation Index (NDVI) was conducted on the Landsat imagery while hillshaded relief image was generated from the DEM. Sobel filter was applied in the four principal directions on ASTER DEM (Table 7). To eliminate bias and subjectivity, the DEM and NDVI of the study area were processed for detection of lineaments. DEMs have shown to be useful for detecting lineaments because they can eliminate bias caused by inherent East-West sun illumination (Henderson et al. 1996; Yun and Moon 2001). Studies that detect lineaments from DEMs alone rely on the assumption that majority of lineaments in a given area are geomorphic rather than tonal. This assumption is valid for most regions as valley and cliff orientations are typically controlled by faulting direction (Yun and Moon 2001). The DEM was processed, and a hillshade surface with a vertical exaggeration of $2 \mathrm{X}$ was produced using ArcGIS ${ }^{\mathrm{TM}}$ Surface Analysis tool. Lineaments occurring in hill-shaded relief images are commonly associated with variations occurring as sun illuminations. These are in turn related to changes in slope gradient. These changes reveal linear features. A $3 \times 3$ filter in the $\mathrm{x}$-direction was applied to enhance the visibility of linear features occurring in the east and west as a result of changes occurring in that direction. It was also repeated in the y-direction for those occurring in the North and South. Inherent in this image were geomorphic
Table 6 Clay and sand content of soil series

\begin{tabular}{lllll}
\hline Soil association & Soil series & Clay content & Sand content & CN \\
\hline Iwo & Iwo & Very low & Very high & A \\
& Ibadan & Low & High & A \\
Ondo & Fagbo & Moderate & Moderate & B \\
& Ondo & High & Low & C \\
Itagunmodi & Araromi & Very high & Very low & D \\
Jago & No series identifiable & Not applicable & Not applicable & D \\
\hline
\end{tabular}


Table 7 Sobel filters applied in four principal directions

\begin{tabular}{llllllllllll}
\hline N-S & \multicolumn{1}{l}{ NE-SW } & \multicolumn{3}{c}{ NW-SE } & \multicolumn{3}{c}{ E-W } \\
\hline-1 & 0 & 1 & -2 & -1 & 0 & 0 & 1 & 2 & -1 & -2 & -1 \\
-2 & 0 & 2 & -1 & 0 & 1 & -1 & 0 & 1 & 0 & 0 & 0 \\
-1 & 0 & 1 & 0 & 1 & 2 & -2 & -1 & 0 & 1 & 2 & 1 \\
\hline
\end{tabular}

lineaments, especially those occurring along fault-controlled cliffs (Anifowose and Aladejana 2016).

The NDVI which is based on the theory of a difference in reflectance in the near infrared (NIR) and red bands of the electromagnetic spectrum has its roots in this application. Its valid results fall between -1 and +1 with higher values indicating more green vegetation. Band 4 (NIR) and Band 3 (Red) were used for this procedure as shown in Eq. 12:

$N D V I=N I R-R E D / N I R+R E D$

This technique has its foundation on the fact that luscious vegetation in hard rock terrains usually aligns with water-bearing fractures (Mogaji et al. 2011). Those with denser and more active vegetations aligned in linear to curvilinear patterns were extracted appropriately by digitizing. The final lineament map digitized was overlaid on the topographic map and Google Earth ${ }^{\circledR}$ imagery of the study area to eliminate man-made non-geologic features such as roads and electric lines.

Lineament density is defined as the ratio of total digitized lineaments divided by the area under consideration (Edet et al. 1994). To derive the lineament density of the study area, the lineament map was converted into a quantitative model as earlier mentioned under Drainage Density. The study area was gridded using the fishnet tool of ARCGIS ${ }^{\mathrm{TM}}$. The grid size was set to $3.7 \mathrm{~km}^{2}$ per grid. The digitized lineament map was overlaid on the grid map in ARCGIS $^{\mathrm{TM}}$. The total length of all lineaments in each grid which gives the lineament density (Ld) of the study area is calculated and interpolated using kriging technique according to Eq. 13.

$L d=\sum_{i=1}^{i=n} \frac{L_{i}}{A}\left(k m^{-1}\right)$

where $\sum L_{i}$ is the total length of all lineaments $(\mathrm{km})$ and $A$ is the area of the grid $\left(\mathrm{km}^{2}\right)$.

The derived lineament density map of the study area is shown in Fig. 4a. It was grouped into 5 classes based on natural break. Lineaments are important as they serve as conduits for groundwater accumulation and movement in basement terrains (Al-Saud 2010). Studies have established that areas with high lineament densities have high groundwater potential (Khairul et al. 2000; Travaglia and Dianelli 2003).

\section{Drainage density}

The drainage system was obtained from the topographic map covering the study area. Drainage pattern shows the spatial distribution of streams over the underlying geology of an area (Adiat et al. 2012; Magesh et al. 2012). It is one of the most important indicators of hydrogeological features, because drainage pattern and density are controlled in a fundamental way by the underlying lithology, vegetation type, infiltration rate, slope angle and the capacity of soils to absorb rainfall (Manap et al. 2012). In addition to this, it is a reflection of the rate that precipitation infiltrates compared with the surface runoff. The infiltration/runoff relationship is controlled largely by permeability, which is in turn a function of the rock type and fracturing of the underlying rock or surface bedrock (Edet et al. 1998). According to Mogaji et al. (2014), drainage density is the ratio of the sum of length of streams to the size of the area of grid under consideration. To derive the drainage density of the study area, the drainage pattern of the study area was converted into a quantitative model using measures proposed by (Al-Saud 2008; Sener et al. 2005; Edet et al. 1998). The study area was gridded using the Fishnet tool of ArcGIS $^{\mathrm{TM}}$. The grid size was set to $3.7 \mathrm{~km}^{2}$ per grid. This small size was used to compensate for the variations in local geology that occur in the study area. The extracted drainage map was overlaid on the grid map in ArcGIS ${ }^{\mathrm{TM}}$. The total length of all drains in each grid which gives the drainage density (Dd) is calculated and interpolated using kriging technique according to Eq. 14 (Sener et al. 2005; Al-Saud 2008).

$D d=\sum_{i=1}^{i=n} \frac{D_{i}}{A}\left(k m^{-1}\right)$

where $\sum D_{i}$ is the total length of all streams $(\mathrm{km})$ and $A$ is the area of the grid $\left(\mathrm{km}^{2}\right)$.

The derived drainage density map of the study area is shown in Fig. 4b. It was classified into 5 classes using the natural break classification algorithm.

\section{Rainfall}

Rainfall, the major form of precipitation determines the amount of water available to percolate into the subsurface. It is a major source of groundwater recharge. For this study, rainfall data for a period of 10 years were obtained from NIMET (Nigerian Meteorological Agency). Since the information was represented as point data, they were interpolated using Inverse Distance Weighted (IDW) to generate data for areas close by, and also for the generation of a raster map that can be used for analysis. The resulting 


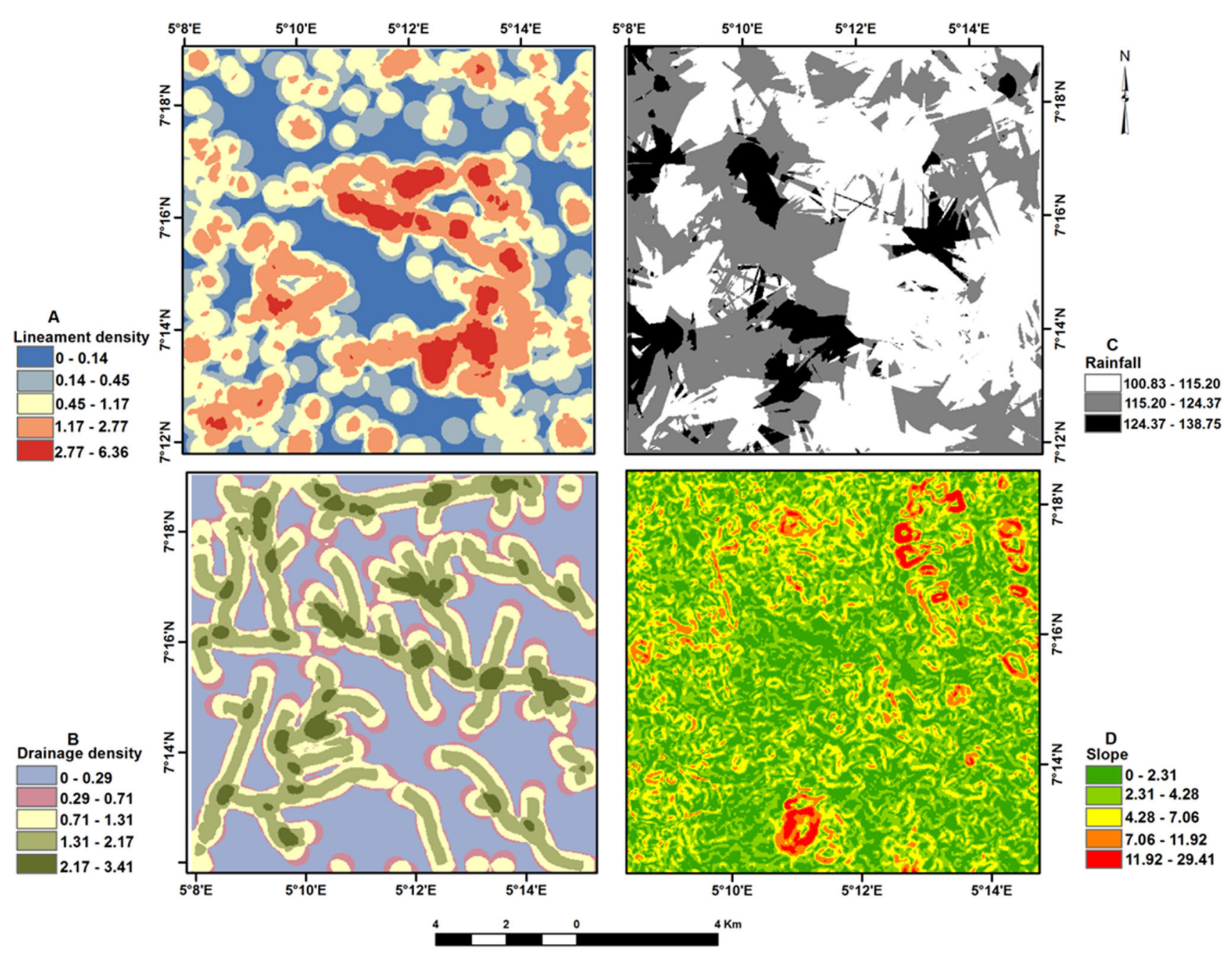

Fig. 4 a Lineament density, b drainage density, $\mathbf{c}$ rainfall, $\mathbf{d}$ slope

map was grouped into 3 classes which are 100.83-115.20, 115.20-124.37, and 124.37-138.75 mm/year (Fig. 4c).

\section{Slope}

Slope influences the accumulation of groundwater in the environment. Flat areas where the slope amount is low are capable of holding rainfall, which in turn facilitates recharge, whereas in elevated areas where the slope amount is high, there is high run-off and low infiltration (Ettazarizini and El Mahmouhi 2004; Prasad et al. 2008). The slope of the study area was generated from ASTER DEM which was projected to WGS 84 Northern Hemisphere Zone 31 , and the pixel size changed to $30 \mathrm{~m}$. The derived DEM was used for slope calculation (degrees) in a GIS environment according to Eq. 15.

Slope $=\operatorname{ATAN}\left(\sqrt{\left(\left[\frac{d z}{d x}\right]^{2}+\left[\frac{d z}{d y}\right]^{2}\right)}\right) \times 57.29578$
The final slope map was grouped into five classes as shown in Fig. 4d. The standard for the evaluation of slope layer according to (European Commission 1995) (Table 8) was applied to determine the groundwater storage potentiality of the slope classes.

\section{Groundwater potential delineation area using weighted overlay}

The groundwater potential map resulting from weighted index overlay analysis is shown in Fig. 5. The map reveals five major classes of groundwater potential levels namely very good, good, moderate, fair and poor potentials. The areas covered by the poor, fair, moderate, good and very good groundwater potential types in the study area are 4.6, $53.3,82.22,37.47$, and $0.43 \mathrm{~km}^{2}$, respectively. In terms of the geology, good groundwater potential points occur mainly on the quartzite rocks and the porphyritic granite 
Table 8 Regional slope classification based on Soil Terrain (SOTER) model

\begin{tabular}{lll}
\hline Slope $(\%)$ & Classification & $\begin{array}{l}\text { Groundwater storage } \\
\text { potentiality }\end{array}$ \\
\hline $0-2$ & Flat & Very high \\
$2-8$ & Undulating & High \\
$8-15$ & Rolling & Moderate \\
$15-30$ & Moderately steep & Low \\
$30-60$ & Steep & Very low \\
\hline
\end{tabular}

rocks. This is definitely as a result of the high level of secondary porosity of these two rock types.

They are very brittle rocks with fractures which serve as natural conduits and hosts for groundwater accumulation. From the hydrogeological point of view, the frequency and extent of jointing, fracturing and flow contacts and weathering along them are the most significant parameters imparting permeability and porosity for forming suitable groundwater reservoirs. In terms of geomorphology, they occur in areas that are plains and alluvial plains. They also occur in areas of high lineament density and intersection, with relatively flat slopes. This result further enunciates the fact that geology, lineaments, geomorphology and slope are the major hydrogeological factors that determine the groundwater potential of any area in particular (Table 9). Areas with moderate groundwater prospects are attributed to contributions from combinations of the land use/cover, lithology, slope and landform. The low to poor categories of groundwater potential zones are spatially distributed mainly along ridges where slope class is very high, the lithology is compact/massive and far from lineaments. Based on borehole information obtained from Ondo State Water and Sanitation Agency (WATSAN) (Table 10), the accuracy assessment of the GWP map was done. There are 34 boreholes and wells with yield ranging from 0 to $4.8 \mathrm{l} / \mathrm{s}$.. The yield was classified thus: poor 0 to $1.0 \mathrm{l} / \mathrm{s}$; fair 1.1 to $1.5 \mathrm{l} / \mathrm{s}$; moderate 1.6 to $2.5 \mathrm{l} / \mathrm{s}$; $\operatorname{good} 2.6$ to $4.5 \mathrm{l} / \mathrm{s}$; very good $>4.6 \mathrm{l} / \mathrm{s}$. When their locations were plotted directly into the GIS environment and overlaid with

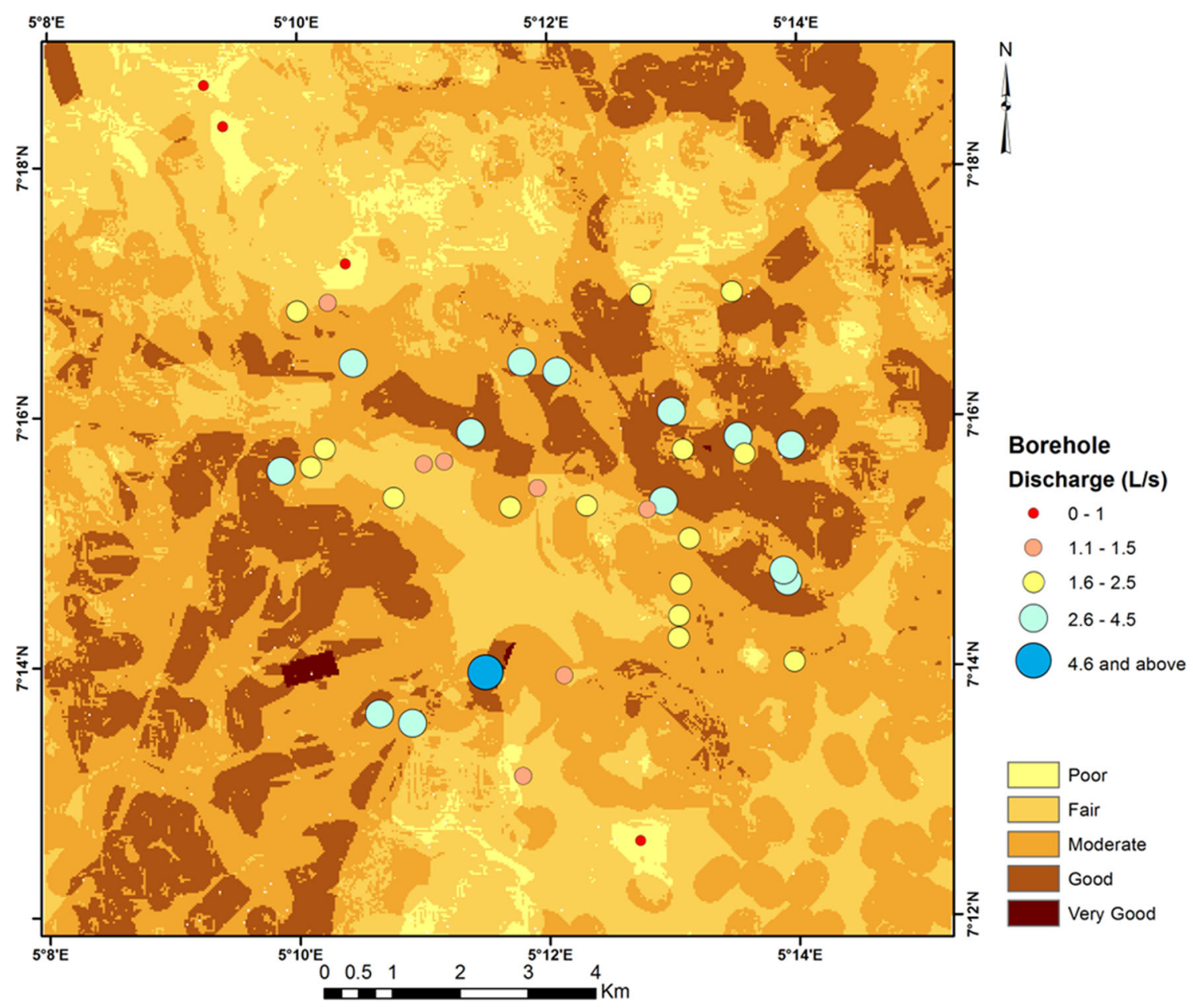

Fig. 5 Groundwater potentials (GWP) and borehole discharge in the study area 
Table 9 Classification of weighted factors influencing the potential zones

\begin{tabular}{|c|c|c|c|c|}
\hline Factor & Data source & Classes & Class rank & Factor weight \\
\hline \multirow[t]{6}{*}{ Land use/cover } & \multirow[t]{6}{*}{ Landsat/IKONOS } & Forest & 41 & \multirow[t]{6}{*}{30} \\
\hline & & Arable land & 26 & \\
\hline & & Bare surface & 17 & \\
\hline & & Settlement & 8 & \\
\hline & & Rock & 5 & \\
\hline & & Water body & 3 & \\
\hline \multirow[t]{6}{*}{ Geology } & \multirow[t]{6}{*}{ Geological Survey of Nigeria, Sheet 61 1:250,000 } & Quartzite & 46 & \multirow[t]{6}{*}{22} \\
\hline & & Biotite granite & 18 & \\
\hline & & Porphyritic granite & 19 & \\
\hline & & Granite gneiss & 9 & \\
\hline & & Migmatite gneiss & 6 & \\
\hline & & Charnockite & 3 & \\
\hline \multirow[t]{6}{*}{ Soil } & \multirow[t]{6}{*}{ Soils derived from crystalline rocks, western Nigeria $1: 50,000$} & Ibadan & 49 & \multirow[t]{6}{*}{19} \\
\hline & & Iwo & 20 & \\
\hline & & Ondo & 15 & \\
\hline & & Araromi & 8 & \\
\hline & & Fagbo & 5 & \\
\hline & & Jago & 3 & \\
\hline \multirow[t]{5}{*}{ Slope } & \multirow[t]{5}{*}{ ASTER DEM } & Flat & 49 & \multirow[t]{5}{*}{12} \\
\hline & & Gentle & 26 & \\
\hline & & Moderate & 15 & \\
\hline & & Steep & 7 & \\
\hline & & Very steep & 3 & \\
\hline \multirow[t]{3}{*}{ Rainfall } & \multirow[t]{3}{*}{ NIMET } & High & 67 & \multirow[t]{3}{*}{7} \\
\hline & & Moderate & 24 & \\
\hline & & Low & 9 & \\
\hline \multirow[t]{5}{*}{ Lineament density } & \multirow[t]{5}{*}{ ASTER DEM and Landsat } & Very far & 3 & \multirow[t]{5}{*}{5} \\
\hline & & Far & 6 & \\
\hline & & Moderate & 14 & \\
\hline & & Close & 26 & \\
\hline & & Very close & 51 & \\
\hline \multirow[t]{5}{*}{ Drainage Density } & \multirow[t]{5}{*}{ Topographic map Sheet 244 (Ado Ekiti) 1:100,000 } & No drainage & 52 & \multirow[t]{5}{*}{3} \\
\hline & & Low & 24 & \\
\hline & & Moderate & 15 & \\
\hline & & High & 6 & \\
\hline & & Very high & 3 & \\
\hline \multirow[t]{3}{*}{ Geomorphology } & \multirow[t]{3}{*}{ Landsat/ASTER } & Alluvial Plain & 55 & \multirow[t]{3}{*}{2} \\
\hline & & Plain & 35 & \\
\hline & & Highland & 10 & \\
\hline
\end{tabular}

the groundwater potential map of the Akure area, the result of this research, various patterns were noticed. Variations occurred in the fair and moderate groundwater potential classes. These variations occurred as a result of variations in the local geology of Akure area. These cannot be accurately accounted for, using only remote sensing and GIS techniques.

\section{Runoff determination using SCS-CN Approach}

The amount of rainfall transported via overland flow is referred to as runoff. This study implemented soil series, land cover, topography (flow accumulation), and rainfall as determinants of runoff in the study area. DEM was processed for flow accumulation to determine where water 
Table 10 Borehole locations

\begin{tabular}{|c|c|c|c|c|c|}
\hline No. & Name & Easting & Northing & Discharge (L/s) & GWP \\
\hline 1 & Alagbaka & $744,858.968$ & $801,345.15$ & 1.6 & Moderate \\
\hline 2 & FUTA Area & $739,660.283$ & $805,482.94$ & 1.3 & Fair \\
\hline 3 & Oke-Aro Road & $749,419.054$ & $799,441.85$ & 2.6 & Good \\
\hline 4 & Off New Stadium & $742,506.582$ & $804,607.55$ & 2.5 & Good \\
\hline 5 & Off Oba Adesida Road & $743,471.186$ & $802,495.12$ & 1.6 & Moderate \\
\hline 6 & Off Ijapo Road & $743,030.116$ & $804,464.48$ & 3 & Good \\
\hline 7 & Oba-Ile Road & $746,484.238$ & $803,400.77$ & 2.7 & Good \\
\hline 8 & Orita Obele Area & $738,104.025$ & $808,081.1$ & 0.8 & Poor \\
\hline 9 & Alagbaka Road & $744,608.408$ & $802,561.56$ & 3.1 & Good \\
\hline 10 & Oja Area & $742,749.347$ & $802,754.57$ & 1.1 & Fair \\
\hline 11 & Express Road & $744,264.506$ & $805,607.99$ & 1.8 & Moderate \\
\hline 12 & Bye-pass & $740,616.237$ & $802,613.81$ & 1.6 & Moderate \\
\hline 13 & Off Ministry of Works & $741,372.601$ & $803,137.26$ & 1.3 & Fair \\
\hline 14 & Femi Alewi Street & $746,437.343$ & $801,378.89$ & 2.9 & Good \\
\hline 15 & Alagbaka Area & $744,380.184$ & $802,455.71$ & 2.4 & Fair \\
\hline 16 & Ijare Road & $737,817.936$ & $808,689.77$ & 0.7 & Poor \\
\hline 17 & Leo Area & $739,607.534$ & $803,328.41$ & 1.9 & Moderate \\
\hline 18 & Oke Aro Road & $740,896.495$ & $799,277.07$ & 2.6 & Good \\
\hline 19 & Near School of Nursing & $746,531.134$ & $800,186.69$ & 1.8 & Moderate \\
\hline 20 & Arikawe area & $741,977.343$ & $800,040.85$ & 4.8 & Very good \\
\hline 21 & Behind Min. of Works & $741,064.872$ & $803,108.67$ & 1.3 & Fair \\
\hline 22 & Alagbaka Area & $744,842.585$ & $800,878.37$ & 1.8 & Moderate \\
\hline 23 & Alagbaka Area & $744,950.94$ & $802,021.69$ & 1.6 & Moderate \\
\hline 24 & Ade Super Hotel & $739,197.977$ & $805,365.03$ & 2.3 & Moderate \\
\hline 25 & Ijelu Street & $744,279.947$ & $797,554.51$ & 0.9 & Poor \\
\hline 26 & Oda Road & $744,827.255$ & $800,554.42$ & 1.7 & Moderate \\
\hline 27 & Off Agagu Road & $738,964.4$ & $803,013.84$ & 3.5 & Good \\
\hline 28 & Oba-Ile Road & $745,796.434$ & $803,268.09$ & 2.4 & Moderate \\
\hline 29 & Alejolowo area & $746,374.815$ & $801,544.19$ & 4 & Good \\
\hline 30 & Okuta-Elerinla & $740,021.107$ & $804,592.81$ & 3 & Good \\
\hline 31 & Ijapo Road & $744,889.845$ & $803,328.39$ & 4.2 & Good \\
\hline 32 & Ijapo Estate & $744,717.831$ & $803,3893.4$ & 1.7 & Moderate \\
\hline 33 & Champion Area & $739,399.293$ & $803,068.37$ & 1.9 & Moderate \\
\hline 34 & Expressway & $739,913.974$ & $806,063.7$ & 1 & Poor \\
\hline
\end{tabular}

tends to flow under gravity in the study area. The runoff map was used in assigning weights to the flow accumulation raster. From this method, a terrain based runoff map (Fig. 6) was derived. This serves to provide the flow path of water that will either infiltrate or runoff in the area.

\section{Model validation using derived infiltration zones}

We further attempted to validate the groundwater model using the terrain based runoff map of the study area. This concept relies on the assumption that infiltration is usually the main factor affecting the amount of water available for runoff (Bras 1990), therefore areas with low runoff will have high infiltration rates, and would generally have good groundwater potential and vice versa. To achieve this, random points were generated in the study area using ARCGIS 10 with the study area extent being the constraint. Values from both the GWP and terrain-based runoff map were extracted to the randomly generated points. Linear regression analysis between the GWP map and the terrainbased runoff map was conducted. The regression plot showing the relationship between GWP and infiltration in the area is shown in Fig. 7. A value of 0.80 was obtained as coefficient of determination $\left(R^{2}\right)$, showing that both GWP and infiltration are well fitted. $R^{2}$ suggests that runoff as a function of land cover, hydrologic soil group, rainfall and flow accumulation can be used in verifying the groundwater potentiality of the study area (Fig. 7). 


\section{Conclusions}

There is an urgent need to meet the water requirement of developing countries such as Nigeria, to ameliorate water scarcity problems being experienced. The maximal exploration and management of groundwater resources through the prediction and detection of promising groundwater sites in these countries suitably fills this need. In this study, an integrated and knowledge-based approach for the assessment of groundwater potential sites using remote sensing and GIS techniques was proposed. Eight parameters (geomorphology, land cover, lithology, drainage density, rainfall, slope, lineament density and geology) with different weights were used resulting in the final map. The validity of the generated groundwater potential map was checked using available borehole data. Furthermore, the terrainbased runoff potential map of the area was also generated based on the relationship between runoff, infiltration and groundwater recharge using an empirical hydrological model. This was used to further verify the groundwater

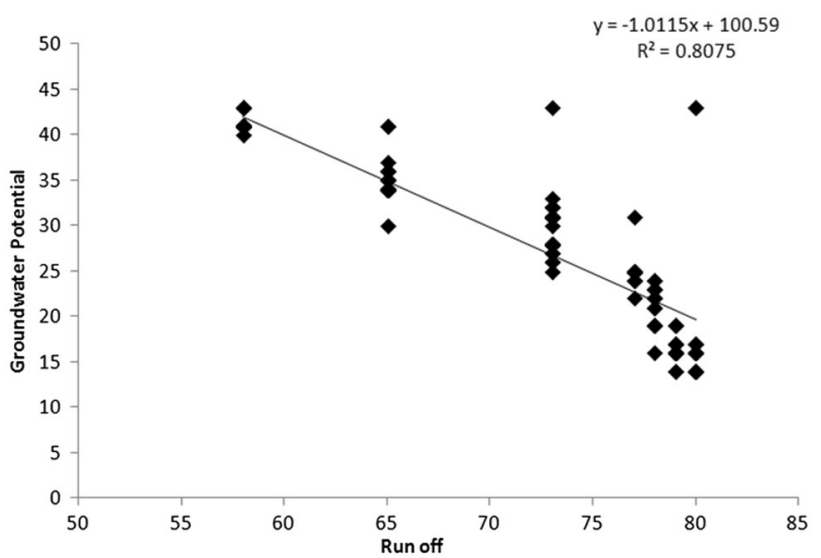

Fig. 7 Regression plot between GWP and runoff

potential map of the study area. The maps obtained can be used by relevant government agencies and private investors as preliminary references to selecting sites for new or proposed boreholes to save costs. As this work uses the SCS-CN approach for runoff and infiltration prediction,

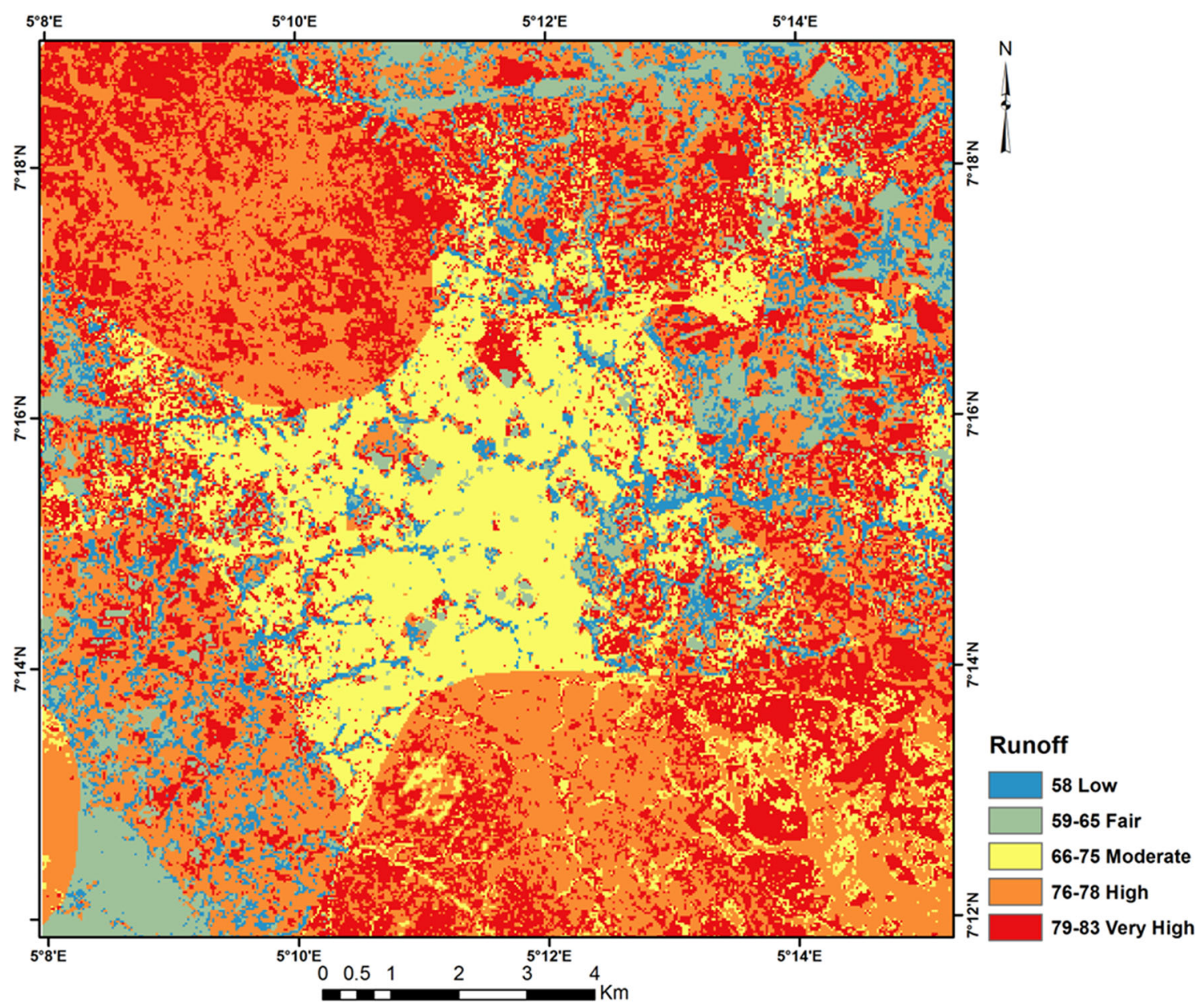

Fig. 6 Terrain based runoff map of the study area 
consequent research works would involve the consideration of the time it requires for the infiltration of rainfall towards groundwater recharge.

\section{References}

Abdalla F (2012) Mapping of groundwater prospective zones using remote sensing and GIS techniques: a case study from the Central Eastern Desert, Egypt. J Afric Earth Sci 70:8-17

Adiat KAN, Nawawi MNM, Abdullah K (2012) Assessing the accuracy of GIS-based elementary multi-criteria decision analysis as a spatial prediction tool-a case of predicting potential zones of sustainable groundwater resources. J Hydrol 440:75-89

Al-Saud M (2008) Using ASTER images to analyze geologic linear features in Wadi Aurnah Basin, western Saudi Arabia. Open Remote Sens J 1:17-25

Al-Saud M (2010) Mapping potential areas for groundwater storage in Wadi Aurnah Basin, western Arabian Peninsula, using remote sensing and geographic information system techniques. Hydrogeol J 18(6):1481-1495

Aladejana OO (2012) Groundwater potential modelling using remote sensing and GIS: a case study of the Akure Area, 94. M. Tech. thesis, The Federal University of Technology, Akure (Unpublished)

Anifowose AYB (2000) Stabilization of lateritic soils as a raw material for building blocks. Bull Eng Geol Environ 58(2):151-157

Anifowose AYB, Aladejana OO (2016) A preliminary Assessment for Groundwater in a Part of North central Nigeria using Landsat ETM+. Global J Geol Sci 14:1-12

Arnold JG, Williams JR, Srinivasan R, King KW (1996) SWAT: soil and water assessment tool. USDA-ARS, Soil and Water Research Laboratory, Grassland, p 194

Atejioye AA, Anifowose AYB (2005) GIS technology in the selection of waste disposal site: a case study. J Res Sci Manag 3(1):66-73

Bala AN, Ike EC (2001) The aquifer of the crystalline basement rocks in Gusau area, North-Western Nigeria. J Min Geol 37(22):177-184

Bras RL (1990) Hydrology—an introduction to hydrologic science, chap 8. Addison-Wesley, Reading, p 643

Chenini I, Mammou AB (2010) Groundwater recharge study in arid region: an approach using GIS techniques and numerical modelling. Comput Geosci 36(6):801-817

Chowdhury A, Jha MK, Chowdary VM (2010) Delineation of groundwater recharge zones and identification of artificial recharge sites in west Medinipur district, West Bengal using RS, GIS and MCDM techniques. Environ Earth Sci 59:1209-1222

Chowdhury A, Jha MK, Chowdary VM, Mal BC (2009) Integrated remote sensing and GIS-based approach for assessing groundwater potential in West Medinipur District, West Bengal, India. Int J Remote Sens 30(1):231-250

Commission European (1995) Soil terrain database. Land Management and Natural Hazards Unit, IES and JRC, European Commission, Brussels, p 81

Dada SS (2006) Proterozoic evolution of Nigeria. In: Oshin O (ed) The basement complex of Nigeria and its mineral resources (A tribute to Prof. M. A. O. Rahaman). Akin Jinad \& Co., Ibadan, Nigeria, pp 29-44

Dar AI, Sankar K, Dar MA (2010) Remote sensing technology and geographic information system modeling: an integrated approach towards the mapping of groundwater potential zones in hard rock terrain, Mamundiyar Basin. J Hydrol 394:285-295

Debo TN, Reese AJ (2002) Municipal stormwater management (electronic copy), 2nd edn. CRC Press Lewis Publishers, New York, p 1176

Deshmukh DS, Chaube UC, Hailu AE, Gudeta DA, Kassa MT (2013) Estimation and comparison of curve numbers based on dynamic land use land cover change, observed rainfall-runoff data and land slope. J Hydrol 492:89-101

de Vries JJ, Simmers I (2002) Groundwater recharge: an overview of processes and challenges. Hydrogeol J 10:5-17

Dinicola RS (1997) Estimates of recharge from runoff at the Hanford Site, Washington, U.S. Geological survey, water-resource investigations report, 97-4038, p 172

Donkor SMK (2003) Development challenges of water resource management in Africa, Pilot Edition. Afric Water J 2003:1-19

Edet AE, Okereke CS, Teme SC, Esu EO (1998) Application of remote sensing data to groundwater exploration: a case study of the cross-river state, Southeastern Nigeria. Hydrogeol J 6:394-404

Edet AE, Teme SC, Okereke CS, Esu EO (1994) Lineament analysis for groundwater exploration in Precambrian Oban massif and Obudu Plateau, SE Nigeria. J Min Geol 30(1):87-95

Ettazarizini S, El Mahmouhi N (2004) Vulnerability mapping of the Turonian limestone aquifer in the phosphate plateau (Morocco). Environ Geol 46:113-117

Ganapuram S, Kumar GT, Krishna IV, Kahya E, Demirel MC (2009) Mapping of groundwater potential zones in the Musi basin using remote sensing data and GIS. Adv Eng Softw 40(7):506-518

Ghayoumian J, Mohseni SM, Feiznia S, Nouri B, Malekian A (2007) Application of GIS techniques to determine areas most suitable for artificial groundwater recharge in a coastal aquifer in southern Iran. J Asian Earth Sci 30(2):364-374

Gitika T, Ranjan S (2014) Estimation of surface runoff using NRCS curve number procedure in Buriganga Watershed, Assam, India-a geospatial approach. Int Res J Earth Sci 2(5):1-7

Gumma MK, Pavelic P (2013) Mapping of groundwater potential zones across Ghana using remote sensing, geographic information systems, and spatial modelling. Environ Monit Assess 185:3561-3579

Guta PK, Panigraphy S (2008) Predicting the spatio-temporal variation of runoff generation in India using remotely sensed input and soil conservation service curve number model. Curr Sci 95(11): 1580-1587

Henderson D B, Ferrill D A, Clarke K C (1996) Mapping geological faults using image processing techniques applied to hill-shaded digital elevation models. Proceedings of IEEE symposium, pp 240-245

Jha MK, Chowdhury A, Chowdary VM, Peiffer S (2007) Groundwater management and development by integrated remote sensing and geographic information systems: prospects and constraints. Water Resour Manage 21(2):427-467

Jha MK, Peiffer S (2006) Applications of remote sensing and GIS technologies in groundwater hydrology: past, present and future. Bayreuth, Bay CEER, p 201

Jones HA, Hockey RD (1964) The geology of part of south-western Nigeria. Geol Surv Nigeria Bull 31:87

Kamaraju MVV, Bhattacharya A, Srinivasa RG, Chandrasekhar RG, Murthy GS, Malleswara RT (1996) Groundwater potential evaluation of west Godavari district, A.P., India-a GIS approach. Groundwater 34(2):318-325

Karanth KR (1987) Groundwater assessment development and management. Tata McGraw Hill Publishing, Noida, p 720

Khairul A, Juhari M A, Ibrahim A (2000) Groundwater prediction potential zone in Langat basin using the integration of RS and GIS. http://www.geospatialworld.net/article/groundwater- 
prediction-potential-zone-in-langat-basin-using-the-integrationof-remote-sensing-and-gis/. Accessed 19 Aug 2016

Khodaei K, Nassery HR (2011) Groundwater exploration using remote sensing and geographic information systems in a semiarid area (southwest of Urmieh, Northwest of Iran). Arab J Geosci 6:1229-1240

Kovalevsky VS (2009) Infiltration and groundwater formation in hydrological cycle. In: Encyclopedia of life support systems (EOLSS), developed under the auspices of the UNESCO, vol III, pp 292. Eolss Publishers, Paris. http://www.eolss.net

Krishnamurthy J, Mani AN, Jayaram V, Manivel M (2000) Groundwater resources development in hard rock terrain: an approach using remote sensing and GIS techniques. Int $\mathbf{J}$ Appl Earth Obs Geoinf 2:204-215

Kumar A (1999) Sustainable utilization of water resources in watershed perspective - a case study in Alaunja watershed, Hazaribagh, Bihar. J Ind soc Remote Sens 27:13-22

Lim KJ, Engel BA, Muthukrishnan S, Harbor J (2006) Effects of initial abstraction and urbanization on estimated runoff using $\mathrm{CN}$ technology. J Am Water Resour Assoc 42(3):629-643

Machiwal D, Jha MK, Mal BC (2010) Assessment of groundwater potential in a semi-arid region of India using remote sensing, GIS and MCDM techniques. J Water Resour Manag 25(5):1359-1386

Madan KJ, Chowdary VM, Chowdhury A (2010) Groundwater assessment in Salboni Block, West Bengal(India) using remote sensing, geographical information system and multi criteria decision analysis techniques. Hydrogeol J 18(7):1713-1728

Magesh NS, Chandrasekar N, Soundranayagam JP (2012) Delineation of groundwater potential zones in Theni district, Tamil Nadu, using remote sensing. GIS and MIF techniques. Geosci Front 3(2):189-196

Maheswaran G, Selvarani AG, Elanogvan K (2016) Groundwater resource exploration in Salem district, Tamil Nadu using GIS and remote sensing. J Earth Syst Sci 125(2):311-328

Manap MA, Nampak H, Pradhan B, Lee S, Sulaiman WNA, Ramli MF (2012) Application of probabilistic-based frequency ratio model in groundwater potential mapping using remote sensing data and GIS. Arab J Geosci 7(2):711-724

Mishra SK, Singh VP (1999) Another look at SCS-CN method. J Hydrol Eng 4(3):257-264

Mogaji KA, Aboyeji OS, Omosuyi GO (2011) Mapping of lineaments for groundwater targeting in the basement complex region of Ondo State, Nigeria, using Remote Sensing and GIS Techniques. Int J Water Resour Environ Eng 3(7):150-160

Mogaji KA, Lim HS, Abdullah K (2014) Regional prediction of groundwater potential mapping in a multifaceted geology terrain using GIS-based Demspter-Shafer model. Arab J Geosci 8(5):3235-3258

Mogaji KA, Omosuyi GO, Adelusi AO, Lim HS (2016) Application of GIS-based evidential belief function model to regional groundwater recharge potential zones mapping in hardrock geologic terrain. Environ Processes 3(1):93-123

Murthy KSR (2000) Groundwater potential in a semi-arid region of Andhra Pradesh: a GIS approach. Int J Remote Sens 21(9):1867-1884

Nolan BT, Healy RW, Taber PE, Perkins K, Hitt KJ, Wolock DM (2007) Factors influencing ground-water recharge in the eastern United States. J Hydrol 332(1-2):187-205

Odeyemi IB, Asiwaju-Bello YA, Anifowose AYB (1999) Remote sensing fracture characteristics of Pan-African Granite batholiths in the basement complex of parts of Southwestern Nigeria. J Technosci 3:56-60

Olorunfemi MO, Ojo JS, Akintunde OM (1999) Hydrogeophysical evaluation of the groundwater potential of Akure Area, Southwestern Nigeria. J Min Geol 35(2):207-228
O'Leary D, Friedman J, Poh H (1976) Lineament, linear, and lineation: some proposed new standards for old terms. Geol Soc Am Bull 87:1463-1469

Ponce VM, Hawkins RH (1996) Runoff curve number: has it reached maturity? J Hydrol Eng 1(1):11-19

Prasad RK, Mondal NC, Banerjee P, Nandakumar MV, Singh VS (2008) Deciphering potential groundwater zone in hardrock through the application of GIS. Environ Geol 55:467-475

Rahaman MA (1988) Recent advances in the study of the basement complex of Nigeria Precambrian geology of Nigeria. Geol Surv Nigeria 3:11-41

Rockstrom J, Lannerstad M, Falkenmark M (2007) Assessing the water challenge of a new green revolution in developing countries. Proc Natl Acad Sci 104(15):6253-6260

Saaty TL (1980) The analytic hierarchy process. McGraw-Hill, New York

Saaty TL (1990) The analytic hierarchy process in conflict management. Int J Conflict Manag 1(1):47-68

Sahid S, Nath SK (2002) GIS integration of remote sensing and electrical sounding data for hydrogeological exploration. J Spatial Hydrol 2:1-10

Sahl M (1987) Geology of Makka Al Mukaramah City area. Saudi Arabian Deputy Ministry for Mineral Resources, Report, p 238

Sander P, Chesley MM, Minor TB (1996) Groundwater assessment using remote sensing and GIS in a rural groundwater project in Ghana: lessons learned. Hydrogeol J 4(3):40-49

Sani Y, Noordin A, Ranya FA (2010) Multi-criteria analysis for flood vulnerable areas in Hadejia-Jama' are river basin, Nigeria. Eur J Sci Res 42(1):71-83

Saraf AK, Choudhury PR (1998) Integrated remote sensing and GIS for groundwater exploration and identification of artificial recharge sites. Int J Remote Sens 19:1825-1841

Satpathy BN, Kanungo BN (1976) Groundwater exploration in Hard rock terrain - a case study. Geophys Prosp 24(4):725-763

Semere S (2003) Remote sensing and GIS: applications for groundwater potential assessment in Eritrea. Environmental and natural resources information systems. Royal Institute of Technology, Stockholm, p 147

Sener E, Davra A, Ozcelik M (2005) An integration of GIS and remote sensing in groundwater investigations: a case study in Burdur. Hydrogeol J 13(5):826-834

Shahid S, Nath SK, Kamal AS (2002) GIS integration of remote sensing and topographic data using fuzzy logic for ground water assessment in Midnapur District, India. Geocarto Int 17(3):69-74

Sharma M, Rao MS, Rathore DS, Krishan G (2014) An integrated approach to augment the depleting groundwater resource in BistDoab, region of Punjab, India. Int J Earth Sci Eng 7(1):27-38

Sharma T, Satya KPV, Singh TP, Trivedi AV, Navalgund RR (2001) Hydrologic Response of a watershed to land use changes. Int $\mathbf{J}$ Remote Sens 22(11):2095-2108

Singh C, Shashtri S, Singh A, Mukherjee S (2011) Quantitative modelling of groundwater in Satluj River basin of Rupnagar district of Punjab using remote sensing and geographic information system. Environ Earth Sci 62:871-881

Singh AK, Prakash SR (2002) An integrated approach of remote sensing, geophysics and GIS to evaluation of groundwater potentiality of Ojhala subwatershed, Mirjapur district, UP, India. In: Asian conference on GIS, GPS, aerial photography and remote sensing, Bangkok-Thailand

Smyth AJ, Montgomery RF (1962) Soils and Land use in central western Nigeria. The Government Printers Ibadan, Western Nigeria, p 265

Soulis KX, Valiantzas JD (2012) SCS-CN parameter determination using rainfall-runoff data in heterogeneous watersheds- the twoCN system approach. Hydrol Earth Syst Sci 16(3):1001-1015 
Suja RS, Krishnan N (2009) Spatial analysis of groundwater potential using remote sensing and GIS in the Kanyakumari and Nambiyar basins, India. J Indian Soc Remote Sens 37:681-692

Travaglia C, Dianelli N (2003) Groundwater search by remote sensing: a methodological approach. F.A.O, Environment and Natural Resources Service Sustainable Development Department, Rome, p 34

Weng Q (2001) Modelling urban growth effects on surface runoff with the integration of remote sensing and GIS. Environ Manage 28(6):737-748

Williams JR (1995) The EPIC model. In: Singh VP (ed) Computer models of watershed hydrology. Water Resources Publications, Highlands Ranch, CO, pp 909-1000
Young RA, Onstad CA, Bosch DD, Anderson WP (1987) AGNPS, agricultural non-point source pollution model: a watershed analysis tool. USDA conservation report 35

Yun S, Moon WM (2001) Lineament extraction from DEM using drainage network. Int J Electr Electron Eng 5(10):2337-2339

Zhan X, Huang M (2004) ArcCN-Runoff: an ArcGIS ${ }^{\text {TM }}$ tool for generating curve number and runoff maps. Environ Model Softw 19(10):875-879

Zhou L, Chen Y (2014) Exploring the potential of community-based grassland management in Yanchi County of Ningxia Hui Autonomous Region, China: an application of the SWOT-AHP method. Environ Earth Sci 72:1811-1820 